1. MBBS, FCPS

Consultant Surgeon

DHQ Attock.

2. MBBS, FCPS

Senior Registrar Surgery

Holy Family Hospital, Rawalpindi.

3. MBBS, MRCS, FCPS

Senior Registrar Surgery

Akbar Niazi Hospital, Islamabad.

4. MBBS

Postgraduate Resident Surgery

Holy Family Hospital, Rawalpindi.

5. MBBS, MRCS, FCPS

6. MBBS, MRCS, FCPS

Senior Registrar Surgery

THQ, Khushab.

7. MBBS, FCPS

Senior Registrar Medicine

District Headquarter Hospital,

Rawalpindi.

8. 4th Year Medical Student $\mathrm{CMH}$, Lahore.

9. MBBS

Postgraduate Resident Surgery

Holy Family Hospital, Rawalpindi.

10. MBBS

Medical Officer Medicine

BHU Dharnal.

Correspondence Address:

Dr. Sara Malik

Department of Surgery

Holy Family Hospital, Rawalpindi.

saramalik087@gmail.com

Article received on:

25/11/2019

Accepted for publication:

$13 / 04 / 2020$

\section{Comparison of early versus late enteral feeding following gut anastomosis.}

\begin{abstract}
Zohra Jabeen ${ }^{1}$, Ramlah Ghazanfor ${ }^{2}$, Muhammad Usman Akram³ ${ }^{3}$ Sara Malik ${ }^{4}$, Maham Tariq ${ }^{5}$, Mehwish Changeez ${ }^{6}$, Javaria Malik ${ }^{7}$, Khawaja Rafay Ghazanfar ${ }^{8}$, Ghulam Khadija ${ }^{9}$, Bilal Ahmad ${ }^{10}$
\end{abstract}

ABSTRACT... Objectives: To compare early feeding versus late enteral feeding following gut anastomosis in term of hospital stay. Study Design: Prospective Randomized Control study. Setting: Surgical Unit 1, Holy Family Hospital, Rawalpindi. Period: April to October 2017. Material \& Methods: All patients, excluding paediatric age group $(n=60)$ undergoing emergency or non-emergency gut resection with primary anastomosis were incorporated. Two strata were devised. Group A $(n=30)$ received early enteral feeding starting at $12^{\text {th }}$ postoperative hours in form of 100-150ml fluid thrice daily. Group B endured being Nil per oral for $72 \mathrm{hrs}$. Both groups were correlated for timing of return of bowel sounds and timespan of hospital stay. $\mathrm{P}$ value $<0.05$ was considered noteworthy. Results: Overall 60 patients with 30 in each group were incorporated. They were predominantly males (55\%) and belonged to middle age group (Group $A=31.73 \pm 10.78$ years; Group $B=36.00 \pm 10.53$ years). Mean time for return of bowel sounds in both the groups was $24.40 \pm 5.88$ hours and $35.20 \pm 10.88$ hours respectively, which was striking ( $p$ value $<0.05$ ). Mean length of hospital stay in both the groups was also noteworthy i.e. $5.23 \pm 0.72$ days and $6.40 \pm 1.67$ days respectively. Conclusion: In the wake of gut anastomosis, early oral feeding at $12 \mathrm{hours}$ is superior to delayed oral feeding after 72 hours, in terms of mean time for return of bowel sounds and period of hospital stay.

Key words: $\quad$ Bowel Sounds, Enteral Feeding, Gut Resection, Gut Anastmosis, Nil Per Oral.

Article Citation: Jabeen Z, Ghazanfor R, Akram MU, Malik S, Tariq M, Changeez M, Malik J, Ghazanfar KR, Khadija G, Ahmed B. Professional Med J 2020; 27(12):25482552. https://doi.org/10.29309/TPMJ/2020.27.12.4355

\section{INTRODUCTION}

Among general surgical procedues, gut operations make up a conspicuous number of both elective and emergency operating theatre lists. The affectees could be enduring a plethora of pathologies ranging from obstructed hernias, post-operative adhesions to tuberculous or enteric perforations etc. All approaches of restoring gut continuity through primary anastomosis, be it hand suturing or stapling, require laborious handling coupled with painstaking post operative monitoring to preclude any possibility of anastomotic blow-out. ${ }^{1}$ Owing to morbidity and mortality of this dreaded complication, the bulk of surgeons let their patients stay unfed rather than take even the remotest risk of anastomotic leak. Hence, the conventional practice is to let the patient fast until resumption of bowel sounds or passage of flatus. ${ }^{2}$
Yet recent times have witnessed a paradigm shift. Emerging surgeons are inclined to forego protracted periods of post-operative fasting. They insist that a substantial bulk of patients having GIT disorders are malnourished to begin with. ${ }^{3}$ Intentional fasting post-operatively may ebb their body reserves. This under nourishment can be a harbinger of an immune compromised state leading to sepsis, wound dehiscence and delayed healing. ${ }^{4}$ On the flip side, timely enteral feeding ameliorates metabolic stress, systemic inflammatory response and bacterial translocation from gut. They believe that since in early post op period patients tend to partake fragile meals and these scarce meals seldom pose any threat to newly anastomosed gut which is already enduring close to ten liters of gastric and pancreatic biliary secretions everyday. In recent past, few international studies have been done to sort this matter out however there is still 
a dearth of local data in this regard. ${ }^{5}$ This aim of this study was to dig out this matter and gather local data. This will aid in making consequential policies for our regional health set-up.

\section{MATERIAL \& METHODS}

This randomized control study was carried out at Surgical Unit 1, Holy Family Hospital, Rawalpindi for a timeframe lasting from April 2017 to October 2017. Validation from Institutional Research Ethics Committee was taken, and those fulfilling inclusion criteria were listed. All patient were above 18 years of age and experienced gut resection and anastomosis on either elective or emergency lists. Patients with a positive history of carcinoma, chemo or radiotherapy, active sepsis, those needing covering stoma or esophageal anastomosis were debarred. Informed consent was taken, and randomization was done by lottery method. In all cases standard single layer extra, mucosal interrupted anastomosis was accomplished by a consultant surgeons. Post operatively patients were kept in general surgical ward with 6 hourly vital monitoring. Patients in Group A were to be given early enteral feeding in the form of $100-150 \mathrm{ml}$ fluid thrice per day, commencing 12hours after gut anastomosis. Group B had to withstand being NPO (nil per oral) for $72 \mathrm{hrs}$ in accordance with conventional protocols. All patients were examined per hour for return of bowel sounds. Extent of hospital stay in both groups was also recorded. Data was interpreted via SPSS version 21.

For qualitative variables like gender, frequencies

\begin{tabular}{|l|l|c|c|c|}
\hline \multicolumn{2}{|c|}{ Two Groups } & n & Mean & Std. Deviation \\
\hline \multirow{2}{*}{ Age of patient } & Group A & 30 & 31.73 & 10.78 \\
\cline { 2 - 5 } & Group B & 30 & 36.00 & 10.53 \\
\hline
\end{tabular}

\begin{tabular}{|c|c|c|c|}
\hline & & \multicolumn{2}{|c|}{ Two Groups } \\
\hline & & Group A & Group B \\
\hline \multirow{6}{*}{ Gender } & \multirow{2}{*}{ Male } & 16 & 17 \\
\hline & & $53.3 \%$ & $56.7 \%$ \\
\hline & \multirow{2}{*}{ Female } & 14 & 13 \\
\hline & & $46.7 \%$ & $43.3 \%$ \\
\hline & \multirow[t]{2}{*}{ Total } & 30 & 30 \\
\hline & & $100.0 \%$ & $100.0 \%$ \\
\hline
\end{tabular}

A sum of 60 patients met the inclusion criteria and were randomized into two groups of 30 patients each. Group A got early enteral feeding at $12^{\text {th }}$ postoperative hour. Contrastingly Group B was made to fast for 72 hours.

Average age in both the groups was $31.73 \pm 10.78$ and $36.00 \pm 10.53$ years respectively. Male patients were marginally increased in numbers i.e. 53.3\% (Group A) and 56.7\% (Group B) Details are specified in Table-I and II.

Average duration for return of bowel sounds (hours) was recorded in both groups (group A $=24.40+5.88$ hours; Group B $=35.20+10.88$ hours). This was found to be statistically remarkable ( $p$-value 0.000$)$. Details are given in also computed (Table-IV).

Effect modifier like gender and age of patients were controlled by stratification. Details are given in Table-V and VI. Table-III. Mean length of hospital stay (days) was

and percentages were taken into account. For
quantitative variables like age, time for return of bowel sounds and length of hospital stay, mean with standard deviation was considered.

Independent sample T-test was used to compare time for return of bowel sounds and duration of hospital stay between two groups. $\mathrm{P}$ value $<0.05$ was considered notable.

\section{RESULTS}




\begin{tabular}{|l|l|l|l|c|c|}
\hline & Two Groups & $\mathbf{n}$ & Mean & Std. Deviation & P-Value \\
\hline \multirow{2}{*}{ Return of bowel sounds (hrs.) } & Group A & 30 & 24.40 & 5.88 & 0.000 \\
\cline { 2 - 6 } & Group B & 30 & 35.20 & 10.88 & \\
\hline
\end{tabular}

Table-III. Comparison of return of bowel sounds (hrs.) in both the groups

\begin{tabular}{|l|l|l|c|c|c|}
\hline & Two Groups & n & Mean & Std. Deviation & P-Value \\
\hline \multirow{2}{*}{ Length of hospital stay (days) } & Group A & 30 & 5.23 & 0.72 \\
\cline { 2 - 6 } & Group B & 30 & 6.40 & 1.67 & 0.001 \\
\hline
\end{tabular}

Table-IV. Comparison of length of hospital stay (days) in both the groups

\begin{tabular}{|c|c|c|}
\hline & \multicolumn{2}{|c|}{$\begin{array}{l}\text { Time duration for return of bowel } \\
\text { sounds }\end{array}$} \\
\hline & $<30$ Hours & $>30$ Hours \\
\hline \multirow{3}{*}{$\begin{array}{l}\text { Gender } \\
\text { Male } \\
\text { Female }\end{array}$} & & \\
\hline & 23 (62.2\%) & $10(43.5 \%)$ \\
\hline & $14(37.8 \%)$ & $13(56.5 \%)$ \\
\hline \multirow{4}{*}{$\begin{array}{l}\text { Age groups } \\
24-40 \text { years } \\
41-50 \text { years } \\
51-60 \text { years }\end{array}$} & & \\
\hline & $33(89.2 \%)$ & $14(66.9 \%)$ \\
\hline & $1(2.7 \%)$ & $5(21.7 \%)$ \\
\hline & $3(8.1 \%)$ & $4(17.4 \%)$ \\
\hline
\end{tabular}

\section{DISCUSSION}

Conventionally, the postoperative management of patients undergoing gut resection involved restraining oral intake of fluids or nutrients until conclusion of the postoperative ileus. Ileus is a predominant determinant of post-surgical convalescence and affects it negatively. ${ }^{6}$ Lately, the approach of perpetuating NPO has been increasingly debated, and rigorous efforts have been made to collect related clinical affirmation.7,8 Previously, trials comparing postoperative fasting to prompt enteral feeding after gastrointestinal resections did not show any obvious edge. However, Dag et al. inferred that early feeding is useful with reference to postoperative complications and duration of hospital stay. In his study, the early enteral feeding group patients resumed oral feeding on the day after the operation without confirmation of bowel motility, and most of these patients successfully put up with it. $\mathrm{He}$ extrapolated that feeding in $85.9 \%$ of the early feeding strata patients was uneventful. ${ }^{1}$ Recently a study based in Iran also affirmed that bowel movements, defecation and time of tolerance of solid diet were appreciably expeditious in the

\begin{tabular}{|c|c|c|}
\hline & \multicolumn{2}{|c|}{ Length of Hospital Stay } \\
\hline & $<5$ Days & >5 Days \\
\hline \multirow{3}{*}{$\begin{array}{l}\text { Gender } \\
\text { Male } \\
\text { Female }\end{array}$} & & \\
\hline & $23(62.2 \%)$ & $10(43.5 \%)$ \\
\hline & $14(37.8 \%)$ & $13(56.5 \%)$ \\
\hline \multirow{4}{*}{$\begin{array}{l}\text { Age groups } \\
24-40 \text { years } \\
41-50 \text { years } \\
51-60 \text { years }\end{array}$} & & \\
\hline & $33(89.2 \%)$ & $14(66.9 \%)$ \\
\hline & $1(2.7 \%)$ & $5(21.7 \%)$ \\
\hline & $3(8.1 \%)$ & $4(17.4 \%)$ \\
\hline
\end{tabular}

batch subjected to early feeding. This insinuate that the timely restarting oral diet in actuality dwindles the spell of ileus rather than sustaining it. $^{9}$

Also, experimental and clinical data prove evidence that early feeding can escalate wound healing and boost anastomotic strength. In colorectal cancer surgery, several randomized controlled clinical trials have already inferred that early oral feeding after elective surgery is risk free and well endured. ${ }^{10}$ Montejo et al. surmised that early feeding initiating the on morning of postoperative day I had a positive outcome in patients having major resections for esophageal, gastric, and pancreatic malignancies ${ }^{12}$ Other publications also seconded that early postoperative feeding, along with being possible, leads to improved protein kinetics and enhanced preservation of the immune system.

Since oral feeding utilizes the natural digestion pathway, it has both nutritional and immunological advantages by amplifying wound healing and increasing resistance to infection. ${ }^{11}$ These 
prospects are reinforced by data of Hur. $\mathrm{H}$, which declare a decreased occurrence of infectionrelated complications in the patients who were started on enteral feed early, even though the difference did not amount to being statistically consequential. ${ }^{10}$

Recent advances in postoperative management have targeted expeditious return towards normal function. Several researchers have suggested a multimodal program including optimal pain alleviation, stress mitigation, expeditious mobilization, and early oral feeding improved physical activity and truncated hospital stay following gut anastomosis. ${ }^{13,14}$

Bufo et al. established that patients who indulged in early oral feeding after gut surgery had a abbreviated postoperative hospital stay (5.7 days) in contrast to those who did not tolerate early oral feeding (8 days), thereby exhibiting another advantage of early enteral feeding. ${ }^{15}$ If early enteral feeding muffles the rate of infectious complications and prunes the length of hospital stay, then the receding risk for prolonged hospitalization would be well worth the cost.

\section{CONCLUSION}

To conclude, early enteral feeding after bowel anastomosis, upgrades patient results in terms of prompt resumption of normal peristaltic activity and shrinking hospital stay.

Copyright(C) 13 Apr, 2020.

\section{REFERRENCES}

1. Dag A, Colak T, Turkmenoglu O, Gundogdu R, Aydin S. $A$ randomized controlled trial evaluating early versus traditional oral feeding after colorectal surgery. Clinics. 2011 Dec; 66(12):2001-5.

2. Han-Geurts IJM, Hop WCJ, Kok NFM, Lim A, Brouwer $\mathrm{KJ}$, Jeekel J. Randomized clinical trial of the impact of early enteral feeding on postoperative ileus and recovery. Br J Surg. 2007 May; 94(5):555-61.

3. Mosquera C, Koutlas NJ, Edwards KC, Strickland A, Vohra NA, Zervos EE, et al. Impact of malnutrition on gastrointestinal surgical patients. J Surg Res. 2016 Sep 1; 205(1):95-101.
4. Chamblee TB, Smith S, Shuster MH, Haight K. Looking beyond the first impression: Malnutrition in the Hospital Setting. Clin Nurse Spec. 2017 Oct; 31(5):235.

5 Sierzega M, Choruz R, Pietruszka S, Kulig P, Kolodziejczyk P, Kulig J. Feasibility and outcomes of early oral feeding after total gastrectomy for cancer. J Gastrointest Surg. 2015 Mar 1; 19(3):473-9.

6. Johnson MD, Walsh RM. Current therapies to shorten postoperative ileus. Cleve Clin J Med. 2009; 76(11):641-8.

7. Negi A, Kumar D, Rajput NS, Pandey A, Gawer D, Ansari $A A$. Early removal of nasogastric tube with early feeding versus conventional removal of nasogastric tube with delayed feeding after bowel anastomosis: A prospective randomized controlled trial. Int Surg J. 2019 Mar 26; 6(4):1380-4.

8. Willcutts KF, Chung MC, Erenberg CL, Finn KL, Schirmer $\mathrm{BD}$, Byham-Gray LD. Early oral feeding as compared with traditional timing of oral feeding after upper gastrointestinal surgery [Internet]. 2016 [cited 2019 Sep 27]. Available from: https://www.ingentaconnect. com/content/wk/sla/2016/00000264/00000001/ art00015.

9. Nematihonar B, Yazdani A, Falahinejadghajari R, Mirkheshti A. Early postoperative oral feeding shortens first time of bowel evacuation and prevents long term hospital stay in patients undergoing elective small intestine anastomosis. Gastroenterol Hepatol Bed Bench. 2019; 12(1):25-30.

10. Hur H, Si Y, Kang WK, Kim W, Jeon HM. Effects of early oral feeding on surgical outcomes and recovery after curative surgery for gastric cancer: Pilot study results. World J Surg. 2009 Jul 1; 33(7):1454-8.

11. Jaffe L, Wu S. The Role of Nutrition in Chronic Wound Care Management. Podiatry management. The diabeticfoot. 2017;36(9):77-82.

12. Montejo JC, Grau T, Acosta J, Ruiz-Santana S, Planas M, García-de-Lorenzo A, et al. Multicenter, prospective, randomized, single-blind study comparing the efficacy and gastrointestinal complications of early jejunal feeding with early gastric feeding in critically ill patients. Crit Care Med. 2002 Apr; 30(4):796.

13. Steenhagen $E$. Enhanced recovery after surgery. Nutr Clin Pract. 2016; 31(1):18-29.

14. Martin L, Gillis C, Atkins M, Gillam M, Sheppard C, Buhler $S$, et al. Implementation of an enhanced recovery after surgery program can change nutrition care practice: A multicenter experience in elective colorectal surgery. J Parenter Enter Nutr. 2019; 43(2):206-19. 
15 .Bufo AJ, Feldman S, Daniels GA, Lieberman RC. Early postoperative feeding. Dis Colon Rectum. 1994 Dec 1; 37(12):1260-5.

\begin{tabular}{|c|c|c|c|}
\hline \multicolumn{4}{|c|}{ AUTHORSHIP AND CONTRIBUTION DECLARATION } \\
\hline Sr. \# & Author(s) Full Name & Contribution to the paper & Author(s) Signature \\
\hline 1 & Zohra Jabeen & Conception of data. & tert \\
\hline 2 & Ramlah Ghazanfor & Drafting Article. & \\
\hline 3 & M. Usman Akram & Critical Revision. & \\
\hline 4 & Sara Malik & Critical Revision. & \\
\hline 5 & Maham Tariq & Critical Revision. & \\
\hline 6 & Mehwish Changeez & Critical Revision. & \\
\hline 7 & Javaria Malik & Critical Revision. & \\
\hline 8 & Khawaja Rafay & Critical Revision. & \\
\hline 9 & Ghulam Khadija & Critical Revision. & \\
\hline 10 & Bilal Ahmad ${ }^{1}$ & Critical Revision. & \\
\hline
\end{tabular}

